\title{
MIIITARY COUPS AND MILITARY REGIMES IN AFRICA
}

\section{2/LT M IAPHET*}

\section{Growth of Military States}

As late as 1961 the African image had not been tarnished to any great extent by the incidence of military coups. Indeed, a field study tour conducted in 1960-1 - the year of independence as it has been called - to investigate the place of the armed forces in societies in Africa did not provide the evidence on which to forecast the eventual spate of coups.

Togo was the first country in West Africa to experience a military coup when on 13 January 1963 Togolese soldiers, recently demobilised from the French colonial armies and facing unemployment as a result of refusal of their applications to join the miniscule Togolese army, staged an armed coup that led to the assassination of President Sylvanus Olympio. At the time Africa's reaction to the coup in Zaire was one of severe disapproval, manifested by vociferous verbal attacks on the junta and international ostracism of the new government until it had legitimated itself through national elections. This can be seen to be largely motivated by the insecurity many civilian governments in Africa were experiencing and was to some considerable extent intended to be an object lesson to aspiring military commanders. At the same time the Organisation for African Unity discussed proposals covering measures to prevent the spread of coups or the legitimation of military regimes, however no common policy was produced.

Witness to the change in the African scenario was the comparative lack of reaction to the 13 January 1967 coup by the Togolese army when they seized power from the government they had previously set up.

In the interim the Congolese and Dahomean armies had presided over the overthrow of Fulbert Youlou in Brazzaville, August 1963, and Hubert Maga in Cotonou, October 1963; in both cases handing over power to another set of civilian rulers. In early 1964 the East African triumvirate was rocked by mutinies leading to new rulers in Kenya, Uganda and Tanganyika; and in February 1964 the Gabonese army toppled Jean Mba's government only to have its coup reversed by French airborne paratroops sent to reinstate De Gaulle's faithful ally. The next spate of coups came in rapid succession as civilian regimes fell in Zaire (then Congo/Leopoldville) on 25 November 1966; Dahomey on 29 November 1965 and again on 22 December 1965; the Central African Republic on 1 January 1966; Upper Volta on 3 January 1966; Nigeria on 15 January 1966 and then again on 29 July 1966 and Ghana on 24 February 1966. This period saw the introduction of the first military governments who had no intention of paying even lip service to democracy through promises to return to a civilian government. Indeed by 1975 twenty of the continent's around fifty states were led by military or civil-military regimes, whilst several others had a record of interference in internal affairs by their military as can be seen in Table 1 . Table 2 gives a geographic distribution of the coup d'états that have taken place since 1950 which should be of interest to social anthropologists.

\section{Nigeria}

Nigeria perhaps, provides a typical example of the part tribalism and factionalism plays in African politics and goes some way in explaining the violent post-independence years. Arbitrary boundaries created by colonial rulers have produced unnatural conglomerations of people thereby exacerbating the, at best, troubled political process. During the first coup in January 1966 a small number of officers, variously calculated at between fourteen and thirty, killed the premiers of the Western and Northern regions as well as the internationally distinguished federal Prime Minister, Sir Abubakar Tafawa Balewa along with a number of senior army officers who, in their judgement, were likely to present problems. With two exceptions, one political and one military, all those killed came from the Western and Northern regions; whilst at least fivesixths of those who took part in the coups came from the East and Mid-West regions, the majority of them being lbos.

\footnotetext{
* 2/Lt M. Japhet, BSc Honns (Bristol University) is at present a National Serviceman at Documentation Services.

This is a reprint of Pointers no 4 , a series which is also distributed by Documentation Services. The Editors of Militaria felt that a reprint of the article, which deals with the underlying causes of military coups and analyses the resulting military regimes, would ensure that it will be brought to the attention of a wider circle of SADF members.
} 
TABLE 1

Sub-Saharan Africa: Incidence of Coups

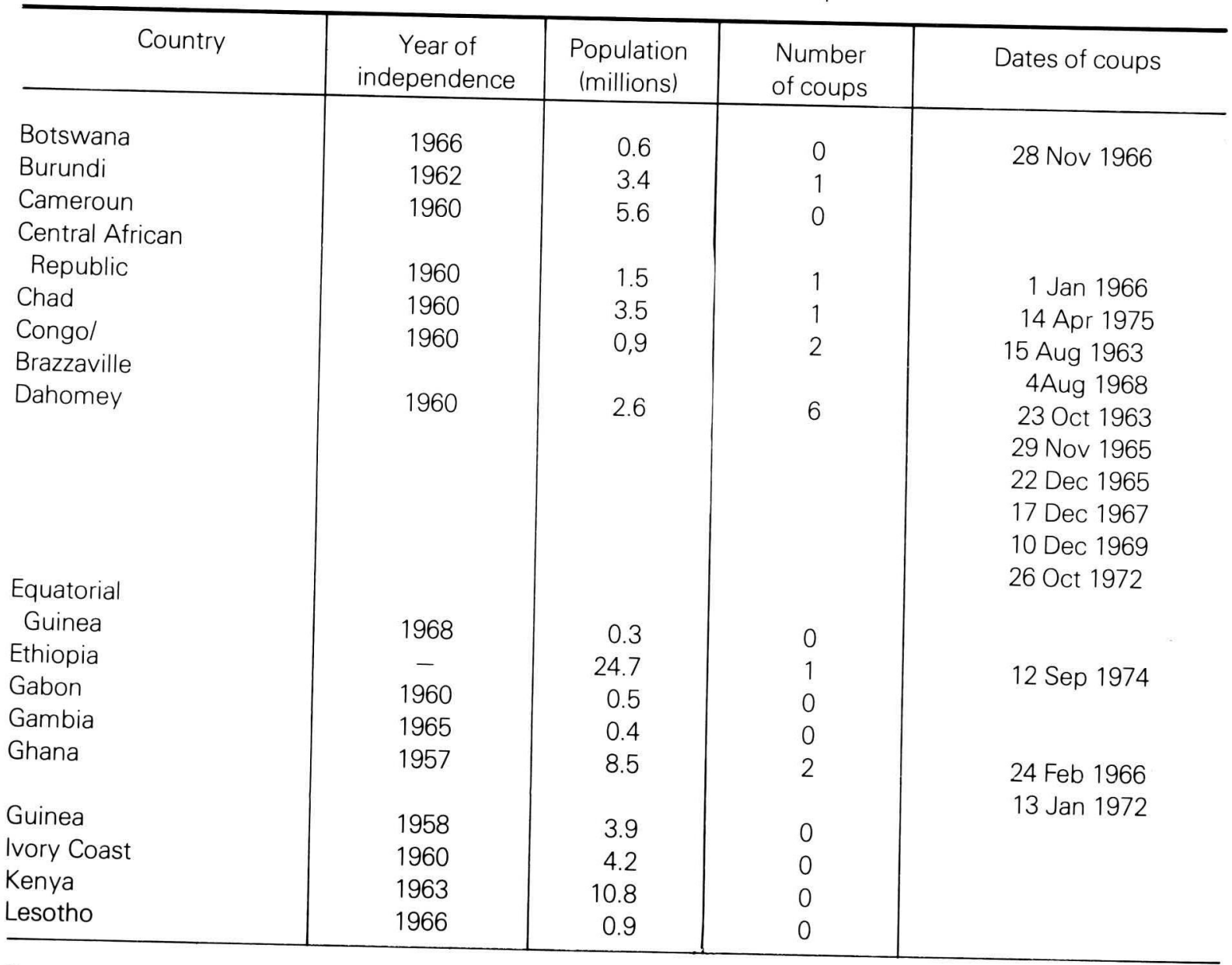

Source: Donald G. Morrison (et al.): Black Africa.

Note: All figures are estimates circa 1967.

Despite the fact that the motives of the perpetrators of the coup were national and ideological rather than regional and factional, it appeared that the Ibos had staged an attack upon all the other ethnic groups and it was this factor that was to dominate the events to follow. Steps subsequently taken by Ironsi, the officer commanding the small original force of some 10000 men, to create one Nigeria were merely seen as attempts to deprive the North of power. A civilian uprising in the North in May 1966 was followed by the assassination of Ironsi and many other Easterners in the army at the end of July. At this point Lieutenant-Colonel Odumegwu Ojubuvu, the military governor of the Eastern region, managed to consolidate the lbos in their heartland and in so doing effectively split the army into two hostile parts thus presaging the civil war arising out of the attempted secession of Biafra at the end of May 1967.

\section{Army Compositions and Instabilities}

This split that developed in the army was made possible by its colonial origins and serves as an example of the inherent instability of all colonially based armies of any size in Africa. Kenya, it is to be remembered, has always had a small army as a result of the positive policy against enlargement carried out during Kenyatta's rule. The requirements of British Imperial policy with its insistence on politically neutral soldiers with a martial tradition from remote areas, combined with the need for relatively welleducated officer material meant that the former came from the less-developed Northern 
TABLE 2

Sub-Saharan Africa: Incidence of Coups

\begin{tabular}{|c|c|c|c|c|}
\hline Country & $\begin{array}{c}\text { Year of } \\
\text { indepence }\end{array}$ & $\begin{array}{c}\text { Population } \\
\text { (millions) }\end{array}$ & $\begin{array}{l}\text { Number } \\
\text { of coups }\end{array}$ & Dates of coups \\
\hline Liberia & 1847 & 1.1 & 0 & \\
\hline Malagasy & 1960 & 7.1 & 1 & 18 May 1972 \\
\hline Malawi & 1964 & 4.4 & 0 & \\
\hline Mali & 1960 & 4.8 & 1 & 19 Nov 1968 \\
\hline Mauritania & 1960 & 1.1 & 0 & \\
\hline Niger & 1960 & 3.9 & 1 & 15 Apr 1974 \\
\hline Nigeria & 1960 & 56.7 & 3 & $\begin{array}{l}15 \text { Jan } 1966 \\
29 \text { Jul } 1966\end{array}$ \\
\hline Senegal & $\begin{array}{l}1962 \\
1960\end{array}$ & $\begin{array}{l}3.5 \\
3.8\end{array}$ & $\begin{array}{l}1 \\
0\end{array}$ & 5 Jul 1973 \\
\hline Sierra Leone & 1961 & $\begin{array}{l}3.0 \\
2.5\end{array}$ & $\begin{array}{l}0 \\
3\end{array}$ & 21 Mar 1967 \\
\hline & & & & $\begin{array}{l}23 \text { Mar } 1967 \\
18 \text { Apr } 1968\end{array}$ \\
\hline Somalia & 1960 & 2.7 & 1 & 21 Oct 1969 \\
\hline Swaziland & 1968 & 0.4 & 0 & \\
\hline Tanzania & 1961 & 12.9 & 0 & \\
\hline Togo & 1960 & 1.8 & 2 & $\begin{array}{l}\text { 13 Jan } 1963 \\
13 \text { Jan } 1967\end{array}$ \\
\hline Uganda & 1962 & 9.5 & 1 & 25 Jan 1971 \\
\hline Upper Volta & 1960 & 5.2 & 2 & $\begin{array}{l}3 \text { Jan } 1966 \\
8 \text { Feb } 1974\end{array}$ \\
\hline Zaire & 1960 & 20.5 & 2 & $\begin{array}{l}14 \text { Sep } 1960 \\
14 \text { Sep } 1960 \\
25 \text { Nov } 1965\end{array}$ \\
\hline Zambia & 1964 & 4.0 & 0 & \\
\hline
\end{tabular}

Source: Donald G. Morrison et al., Black Africa.

Note: All figures are estimates circa 1967.

area whilst the latter were recruited from near the urban areas in the South. The resulting predominance of Northern and Middle Belt other ranks, and conversely of Ibo and other Eastern officers in the middle of the army hierarchy, constituted a dangerous inconvenience in a situation in which political control of the defence forces was in Northern hands.

The situation was not quite that simple, however, since indigenous authority had not had either the time or the conditions in which to become consolidated to the point where subordinates naturally accepted its legitimacy and behaved accordingly. This view certainly aids in understanding men who combined strongly Pan-African sentiments and anti- white racial attıtudes with the country gentleman postures of British officers.

Volatile political conditions prevailing in many African countries reveal the weaknesses and the concealed paradoxes of their military situations. Where there is uncertainty about the duty owed to a political authority whose legitimacy is questioned for any reason, then the inherent conflict between discipline and a high level of independent initiative, which is an essential feature of military institutions, is heightened. Another feature is that of the efficient administrative capabilities found in larger armies that promps intervention in civil affairs on seeing blatant mismanagement, particularly where this leads to an imbalance in the civil service pay 


\section{TABLE 3}

Comparative Characteristics of Overt Military Intervention in Dahomey, Ghana, Sierra Leone, and Mali, $1965-70$.

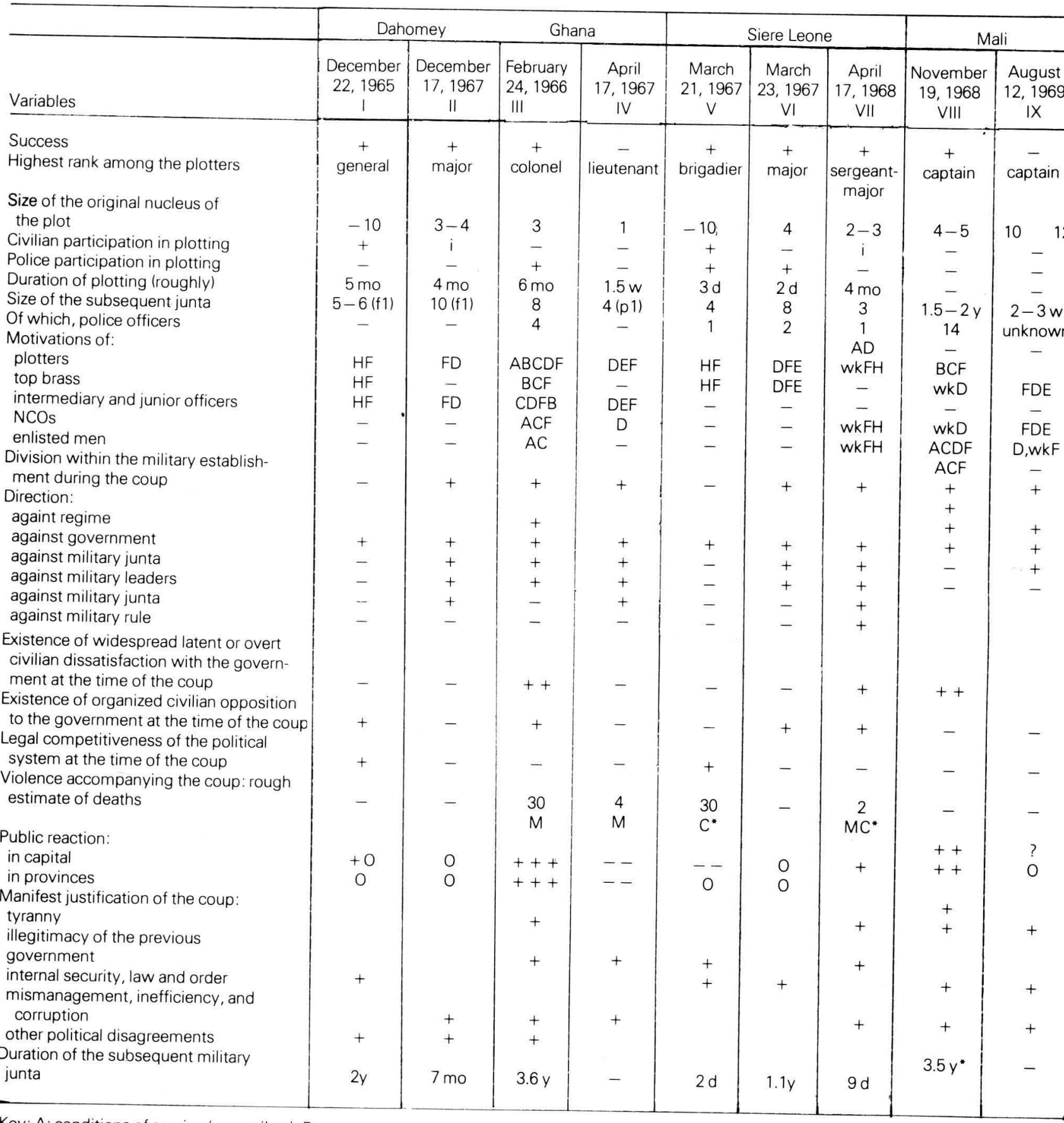

Key: A: conditions of service (pay strikes); B: corporate autonomy; C: corporate and personal security; D: self-promotion; E: other personal; $M C^{*}$ : mixed casualties; O: indifferent.

Explanation of symbols used: i: insignificant; -: approximately; mo: month; $y$ : year; w: week; d: day; pl: planned; fl: fluid; inf: informal; wk: weak + : presence, positive; - : absence, negative.

Source: Military Rule in Africa ed. Bebler A., Praeger Publishers 1973. 
structure with regard to remuneration of the armed services.

The Nigerian situation was aggravated by the lack of an historic military tradition, in the European sense, in that qualities of delegation, deference due to status, flexibility of the response of subordinates to orders from their superiors and the like were insufficiently developed in order to provide the necessary controls and safety valves which normally enable military institutions to survive disruptive tensions.

Another pervading problem that can be applied to African armies in general and that can be observed in the Nigerian context in particular, is that of Africanisation of the officers corps. This has usually been seen in terms of the quantity of young officers commissioned and the corresponding speed of their replacement of expatriates. However the extent of the experience and training of the senior officers has also been viewed as of crucial importance. The Nigerian forces in 1966 included just twenty-two officers with staff training at the Camberley Staff College, the Pakistan Staff College, Quetta, the United States Command and Staff College at Fort Leavenworth or their equivalents. Further it is well known that the Nigerian army of the time was an inherited force consisting of units of the Royal West African Frontier Force recruited from Nigeria and in a few cases from adjoining territories. On gaining independence the transition had to be made from that of the agent of a colonial power, chiefly concerned with the maintenance of internal security to the particular needs of a newly independent and developing African state.

Career patterns and promotion prospects for Nigerians in the Nigerian army from 1956-66 conformed to no established pattern added to which the merits of hierarchy and of personal authority based on status were less obvious in an organisation where small differences in age and length of service separated the top from the bottom. Consequently those in top posts had often not the experience to command respect for their high authority while those lower down were correspondingly frustrated; on top of this a period of rapid promotion was followed by one in which it virtually came to a halt.

Another aspect was the fact that the upper echelons were in many cases disadvantaged by a lack of education, being former Non Commissioned Offi- cers and Warrant Officers and this was of particular importance where then, as now, education and status had a very strong link. In contrast to this, many Non Commissioned Officers were vastly more experienced than their officers; a situation that had been regarded normal in the colonial era. It is interesting to note, therefore, that those commissioned between 1958-9 were to receive the most rapid promotion to major and it was from this group that the conspirators of January 1966 mainly came. Some explanation is necessary. What appears to be the cause was a kind of professional disorientation caused by rapid promotion which resulted in their never being in a post sufficiently long to master the role and to become familiar with the tasks involved. Further it is arguable that the stability of the army was affected in other ways by too rapid promotion. The rotation of battalion commanders for example, the 5th Battalion had four in the space of eighteen months, meant that unit officers were able to act more independently than would otherwise have been possible with a battalion commander who appreciated their strengths, weaknesses and potentialities. A lack of cohesion and a degree of irresponsibility were almost inevitable in these conditions.

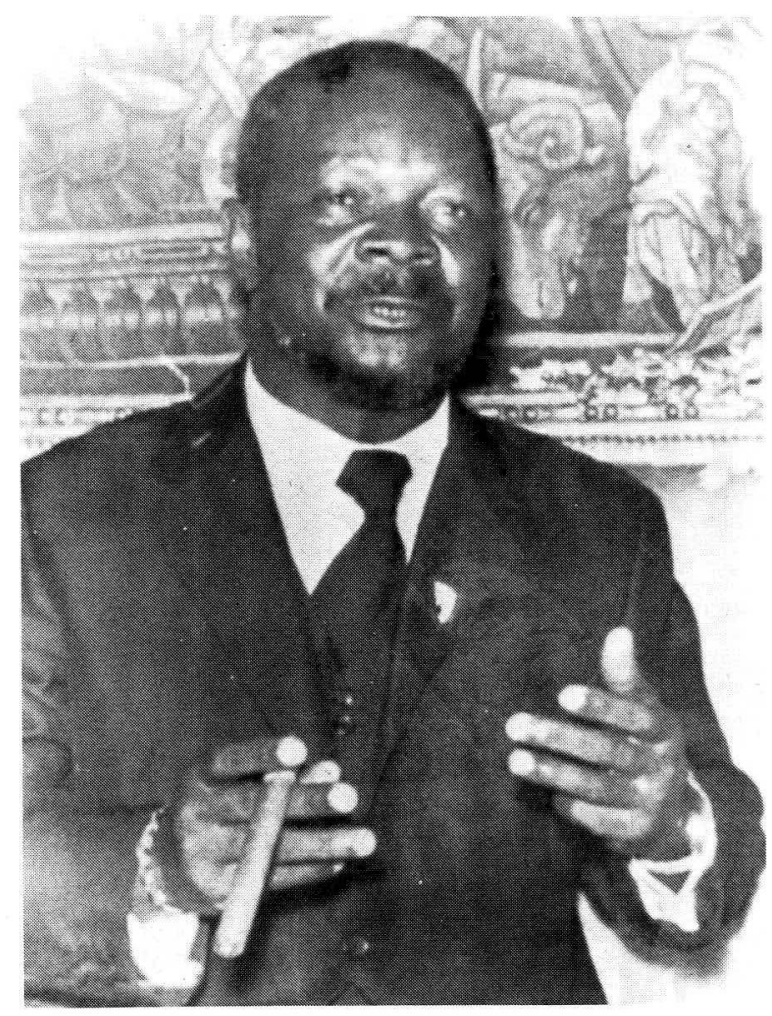

(Photo: Buru for National and International Communication)

Bocasso of Nigeria 


\section{Military Government - Legitimacy and Civilian Rule}

Having established some of the possible causes for and aggravating factors of the coups in Nigeria it is important to follow the perceived role of the military governments with respect to their legitimacy and a subsequent return to civilian rule.

On gaining power, Major-General Ironsi attempted to allay the fears of the public by declaring three days mourning for the murdered federal Prime Minister, Sir Abubakar Tafawa Balewa. At the same time the military government sought to reassure foreign interests by affirming its intention of honouring all treaty obligations and financial agreements. However this activity did not reverse any of the sets of opposites identified in the study of the civil war conducted by A.H.M. Kirk-Green who says:

'In the final analysis, the Nigerian tragedy has been bedevilled by a set of oppositions - generalised, stereotyped, not necessarily of the same order and maybe imaginary, yet each widening the wound and reducing the hope of healing it: North $v$ South, Islam v Christianity, alleged feudalism v assumed socialism, federal $v$ unitary references, traditional authority $v$ achieved elitism, have $v$ have-nots, each with sinister undertones of tension, irreconcilability and threatened withdrawal. None was entirely accurate. Nevertheless each opposing set had sufficient seed of truth within it to permit, and even to fertilise, the growth of feared fact from the semifaction of its existence.'

From the first, apparently genuinely, Irani and his advisers endeavoured to prepare for a return to civilian rule by setting up study groups to form a new constitution. One of the more popular alternatives was that of a presidential system along American lines whereby a military president could draw upon the nation's full reserve of talent for his ministers. This demonstrates the essential connection between the perceived rôle of a military administration and the notion of a national government acting in a crisis. There are signs of a parallel thinking on the part of the Gowon government in relation to 1976: the possibility of a radical constitutional innovation more appropriate to the needs of a rapidly developing state than conventional parliamentary democracy cannot be ruled out.
The chief problem that is encountered by military regimes attempting to find some long-term solution to government is that of finding some formula which enables full consultation and participation to be combined with efficient administration without the disruption and corruption seemingly inseparable from unleashing full-scale political rivalries. The Nigerian military, as with other military establishments elsewhere in Africa, prefer organisations in which there is a clearcut hierarchy, allocation and gradation of responsibility. Ghana has recently been involved in much turmoil over Head of State, General Kutu Acheampong's attempt to return to a military dominated civilian government via his concept of a non-party civilian government. Sensing the electorate's deep resentment of his government's handling of Ghana's economic and social affairs, Acheampong realised that he and his commissioners had not the slightest chance of winning an outright contest against the political parties, many of which were becoming increasingly vociferous in their comments against him. The only hope of maintaining any military influence over Ghana's furture lay in forming a government of military as well as civilian leaders. After putting the Union government proposal to the public in a referendum the result was rigged to give a $54 \%$ vote in favour followed by the banning of the three largest antigovernment parties. Democracy and a return to full civilian rule still seem a long way off in a country that appeared to be well able to overcome the difficulties involved in the transition.

\section{The Importance of Personality}

Studies of the military in African politics have habitually underplayed the unpredictable factor of personality : its contribution to the Nigerian denouement is, however, indisputable as is the case with Uganda and Amin. Ironsi, Gowon and Ojukwu all played a distinctive role by dint of their particular characters. Colonel Yakubu Gowon in particular placed his stamp on Nigeria's history by displaying incredible clemency and skill in reuniting the country after the Biafran war and building the country's economy. At the same time he built the army up from 8000 men to a peak of 200000 or even 250000 men. What is of interest here is that while Ghana, Dahomey and a number of other countries experiencing military rule today possess essentially the same armies, allowing for retirement and elimination of a few senior personnel, as they had before their first coups, Nigeria had essentially a new army. One must bear in mind that apart from the dramatic increase in size, the original officers 
corps in particular was thinned out by the coup of 1966 and suffered heavy casualties during the civil war. This means that the attitude and motivation of those who overthrew the government in 1966 are unlikely to bear much relation to those who overthrew Gowon in 1975.

\section{Gowon's Deposition}

It seems that there were two chief causes for Gowon's deposition on 29 July 1975, both of them reflecting the inherent difficulties and incongruencies contained in military rule. Firstly the officers corps became subject to inter-generational and other divisions largely centering around tribalism and the progress from a semi-backward to an elitist and powerful position. Secondly the success of the Gowon government in unifying and stabilising the country had not been extended to the transition towards a civilian government. Discontent over inflation, widespread corruption, damaging strikes and the twelve state governors' privileged style of living, which had aroused public anger, appeared to crystallise around the General's decision in October 1974 to postpone the return to civilian rule, promised for 1976 in 1970 on the grounds that 'a high degree of sectional politicking' would endanger progress at this time.

The Nigerian situation again illustrates an endemic problem for military regimes that has been selected as their most important aspect, that of a return to civilian rule. Having gained power Gowon then maintained that only a strong centralised government could handle the consequences of a controversial census, meaning that to tackle the problems of a developing country as well as the seemingly inevitable corruption that goes with this development, the military are best placed to quell a conflagration started by an accidental spark caused by a census or some other occurrence.

In his speech of 1 October 1974 Gowon begged the essential question when he said that civilian rule would be postponed until the government had laid 'the foundation of a self-sustaining political system which can stand the test of time in such a manner that each national political crisis does not become a threat to the nation's continued existence as a single entity and which will ensure a smooth and orderly transition from one government to another'.

However Gowon overlooked the difficulties in- volved in attempting to sustain the stability of such a diverse society by freezing political activity and 29 July 1975 consequently saw his overthrow by Brigadier Murtala Rufan Mohammed.

\section{Ghana}

Kwame Nkrumah fell in February 1966 largely as a result of his insensitive handling of the army. He had made himself Supreme Commander of the army and therefore was able to make political appointments as well as which the attribution of subsequent arbitrary actions to the existence of these powers, and growing suspicion about the President's future intentions, seems to have contributed substantially to the change of officer attitudes which eventually made the coup possible.

However where Ghana becomes interesting is in the subsequent events. By September 1969 the Ghanian army had effectively returned to barracks and with the dissolution of the interim Presidential Commission in August 1970, the re-establishment of civilian rule was formally affirmed with Dr Kofi Busia's administration being elected in what is recognised as the best conducted and most democratic election ever held in post-independent tropical Africa. However in less than eighteen months, on 13 January 1972, a new military regime was set up under the leadership of Colonel I.K. Acheampong justifying Busia's overthrow on much the same grounds as Afrifra and his colleagues had used in overthrowing Kwame Nkrumah.

Colonel Acheampong's seizure of power had demonstrated that henceforward no regime in Africa, and West Africa in particular, was safe from military intervention: any government might be overthrown at any time, whatever its record and whatever its democratic credentials. Within the short span of three years, groups within the Ghanian élite had pioneered the route, found so difficult by many other countries, from military to

1. This brief look at various areas that may be identified as symptoms or ingredients of coups and military regimes is intended as by way of introduction to the question of coups and military regimes in general. Those aspects dealt with to date apply, to a greater or lesser extent to the countries dealt with in the rest of the paper. Comments made on each country are intended to highlight particular aspects that are of interest in order to give a fuller picture of the whole. 
civilian rule and then resoundingly demonstrated the futility of the exercise by the swift return to military rule thereafter.

Ghana under Acheampong reached a stage politically, by the end of 1977, whereby some alternative had to be found for a military government and, as has been mentioned before, the idea of a non-party union government that would leave the military in essentially the same position was formulated and put to the public in a rigged referendum. Subsequent to the referendum on 30 March 1978, General Acheamporig was forced to resign by hostile forces within the country's ruling élite who apart from opposing the concept of union government had been angered by the failure of Acheampong to return the country to civilian rule by the end of last year, as had been promised. The new head of the Supreme Military Council, Lieutenant General Fred Akuffo looks headed for a multi-party civilian rule situation as things stand.

On the whole the last ten years in Africa nave tended to substantiate Professor Finer's original suggestion, in 1962, that military initiatives in politics are most often the product of a low level of political culture in circumstances where there has been virtually inevitable economic disappointment, compounded by financial mismanagement. The term 'praetorianism', implying the emergence of the military as an independent political force, has only limited validity when applied to sub-Saharan Africa. The tendency, well illustrated in Ghana, has been for military action to reflect a convergence of military with civilian discontent and for military regimes to be based on the same institutional and personal infrastructure as their civilian predecessors.

\section{Zaire}

Zaire is a clear example of the difficulty of categorising African military regimes rigidly, although this is not to say, as has hopefully been illustrated, that there are not distinct patterns and similarities to be observed. On top of this it also demonstrates the problems involved in defining a military regime for since 1965 , Zaire has been very much the personal domain of General Mobutu.

This commenced when Mobutu and the Armée Nationale Congolaise high command unseated the two rivals for the presidency, Moise Tshombe and Joseph Kasavubu on 24 November 1965, after the popular rebellions of 1964-5. Even more than most military rulers, Mobutu despised politicians and regarded the army as the national depositary for moral rectitude. The new constitution of 1967 saw the dissolution of parliament and meant that Mobutu, as President for seven years initially, had full authority to operate a presidential-style government in which all senior public servants were personal appointments and the distinction between ministers and civil servants was arbitrary. Like many military leaders before and since, including Colonel Acheampong in Ghana and even General Amin in Uganda, Mobutu involved people of all categories and classes in actions of domestic economy, like street cleaning, in order to identify the people with a drive for patriotic emotional commitment.

In order to reduce factional and regional differences as well as potential areas of discontent arising to threaten the status quo, Mobutu altered the number of provinces in stages from twenty-one to eight and in so doing almost restored the pattern which had prevailed during the colonial period.

These provinces were in future to be administered rather than governed; the representative assemblies became advisory bodies and officials were deliberately transferred to areas far away from their place of origin. The alleged tendency for military regimes to restore the forms and relationship of colonial rule was thus classically demonstrated.

One of Mobutu's shrewdest moves was to mobilise the élite by creating a type of 'think tank' drawn from products of Lovanium University. Through this and other measures the military character of the regime faded. The emphasis was on the personality of Mobutu, who himself tended to discard army uniform, in fact there were certain parallels with the overt civilianisation stage of the Nasser administration in Egypt. By preventing civilians from exercising popular appeal in key posts through a high turnover in ministers, as well as by consolidating his personal security through his knowledge of the army acquired in the ranks, Mobutu was able to maintain power.

Whatever the true nature of his regime, then, Mobutu has used the military and civilian apparatus to restore unity and to eliminate overt rebellion; he allowed the rise of an African bougeoisie within an essentially capitalist framework and at the 
same time cultivated the university and its products. His regime since 1965 can be said to have thrown more light on the problems of political behaviour of the military, whom Mobutu has tended to treat as only one of several elements in the balance of forces in Zaire which he has sought to achieve.

\section{Uganda}

In many respects there are similarities to be found between Mobutu's Zaire and Amin's Uganda. Both men were once sergeants in Colonial armies and both asserted their leadership and seized power during a period of mutiny and general military discontent. As with Nigeria, tribalism has been an essential element of the country's politics revolving around the tug-of-war between Bugandan separatism and the idea of a Ugandan nation; between modern political authority based upon nonBuganda regional ethnic alliances and the concept of the supremacy of the Kabaka and traditional authority. Intertwined with this struggle are centreperiphery, Cathlic-Protestant, civil-military and personality competitions.

Amin's power grab was a personal takeover supported by a minority of the armed forces and facilitated by Obote's policy of keeping the army weak through command and factional fragmentation. Hence Amin's coup did not mark his rise to preminence in the army but rather sparked off patricidal intergarrison battles, interethnic massacres, the liquidation of Adoko's General Service force (set up by Obote as a result of the unruliness of the army), and an uncontrolled reign of terror.

Unlike, for example, the military governments of Nigeria and Ghana, the Amin administration acted to reduce the influence not only of politicians but of civil servants. After three years of the new regime, no ideological or conventional rationale of government was yet discernible, the only criterion being individual or group self-interest.

It is interesting, however, to note that Amin commenced his rule in much the same way as other military regimes by attempting to justify the coup and by pledging an interim military administration with a speedy return to competitive politics.
Instead Amin built up the armed forces, coupled with regular purges, to over twenty thousand and moulded them as a force committed to the hegemony of one region, the far North, and loyal to one individual - Amin.

It rapidly became clear that Amin was incapable of either delegating authority or of listening to expert advice and many top rate politicians fled the country. Popularist moves such as the expulsion of the Asians were followed by other moves in the parochial field, rather than in areas that were paramount issues facing Uganda. In the words of the state radio itself, Amin's records after two years in office lapart from having 'expelled' the Asians, British and israelis) was that he had 'resolved all religious differences ... reduced excessive drinking ... abolished mini-dresses'.

Amin has achieved wide press coverage in bizarre moves such as requesting assistance from lan Smith in locating size thirteen shoes for himself and setting up a banana and vegetable collection for the Save Britain Fund!

However, completely isolated from most ethnic groups in Uganda, essentially relying upon alternative purges and populist appeals, his Nubian troops and bodyguard, a highly factionalised army, and the cementing effect of patronage, state allocations and plundered expatriate possessions, Amin's regime may be toppled tomorrow, (there have been no less than six assassination attempts to date), or survive for years. In the former eventuality there will most likely be another period of inter-factional and inter-ethnic violence as a new power group and its leader attempt to gain superiority and the rewards that come with it.

\section{Conclusions}

In looking at the cases of Nigeria, Zaire, Ghana and Uganda with particular emphasis on Nigeria, it is hoped that some idea of commonalities that exist in Africa between the various military regimes and coups has been given. At the same time the range of circumstances in which the military may intervene should also be noted. It could be argued that in Nigeria and Zaire there was little alternative to Gowon and Mobutu. The Ghanian military, however, overthrew a democratically elected government whilst Uganda was not at a critical stage but rather Amin's overthrow was as a result of inter- 
personal rivalries. The inclination may be to assume that the firm hand of a centralised government backed by the required sanctions is what is needed to deal with the chronic economic and sociopolitical problems facing many African countries today, if Colonel Acheampong's progress is taken as an example. However, difficulties lie in comparison insofar as defining what a military regime is. The spectrum ranges from a civilian government wholly dependent on its military forces to a military dictatorship where all the functions of State are carried out by military personnel. Mobutu's case is perhaps the most difficult in that as a result of the centralisation of power and patronage in his hands, the military character of the regime has been obscured and reduced; a system of checks and balances, of dual control and functions at lower level and of deliberate civilianisation marks his government.

A stance of modified nationalism marks most African military regimes, whilst their ability to implement and devise their own policy has been proved. However the one overriding problem that all face is that if they decide to foster the political resurgences necessary for a return direct to civilian rule, they suggest their own illegitimacy; if they continue direct rule in the colonial style, they do little to cultivate the establishment of a viable and self-generating political system regarded as essential to the long term stability and prosperity of their countries.
Bibliography

1. N.U. Akpan: The struggle for secession 1966-70; A personal account of the Nigerian civil war, (London, 1972)

2. S. Andreski: The African predicament: A study of the pathology of modernisation, (1968)

3. D. Apter: The political kingdom in Uganda: A study in the bureaucratic nationalism, (Princeton, 1961)

4. G. Balandier: The sociology of Black Africa: Social dynamics in Central Africa, (1970)

5. J. Bauard: Four equatorial states (In G. Carter (ed): National Unit and Regionalism in eight African States) (1966)

6. A. Bebler: Military rule in Africa; Dahomey, Ghana, Sierra Leone and Mali, (New York, 1973)

7. V. Bennet: The intransferability of patterns of civil and military relations: The case of Ghana (In Special Studies no 20, Council of International Studies, State University of New York, 1972)

8. S. Decalo: The colonel in the command car: Towards a reexamination of motives for military intervention in Africa, (In Cultures et Development, January, 1974)

9. S. Decalo: Coups and army rule in Africa: Studies in military style, New Haven, 1976)

10. The Journal of Developing Areas, April 1973, (U. Eleazu: The role of the army in African politics: A reconsideration of existing theories and practices)

11. S.E. Finer: The man on horseback (London, 1962)

12. M. Janowitz: The military in the political development of new nations: An essay in comparative analysis, (Chicago, 1964)

13. J.J. Johnson (ed): The role of the military in underdeveloped countries, (Princeton, 1962)

14. A.H.M. Kirk-Greene: Crisis and conflict in Nigeria, a documentary sourcebook 1966-69, vol 1, (London, 1971)

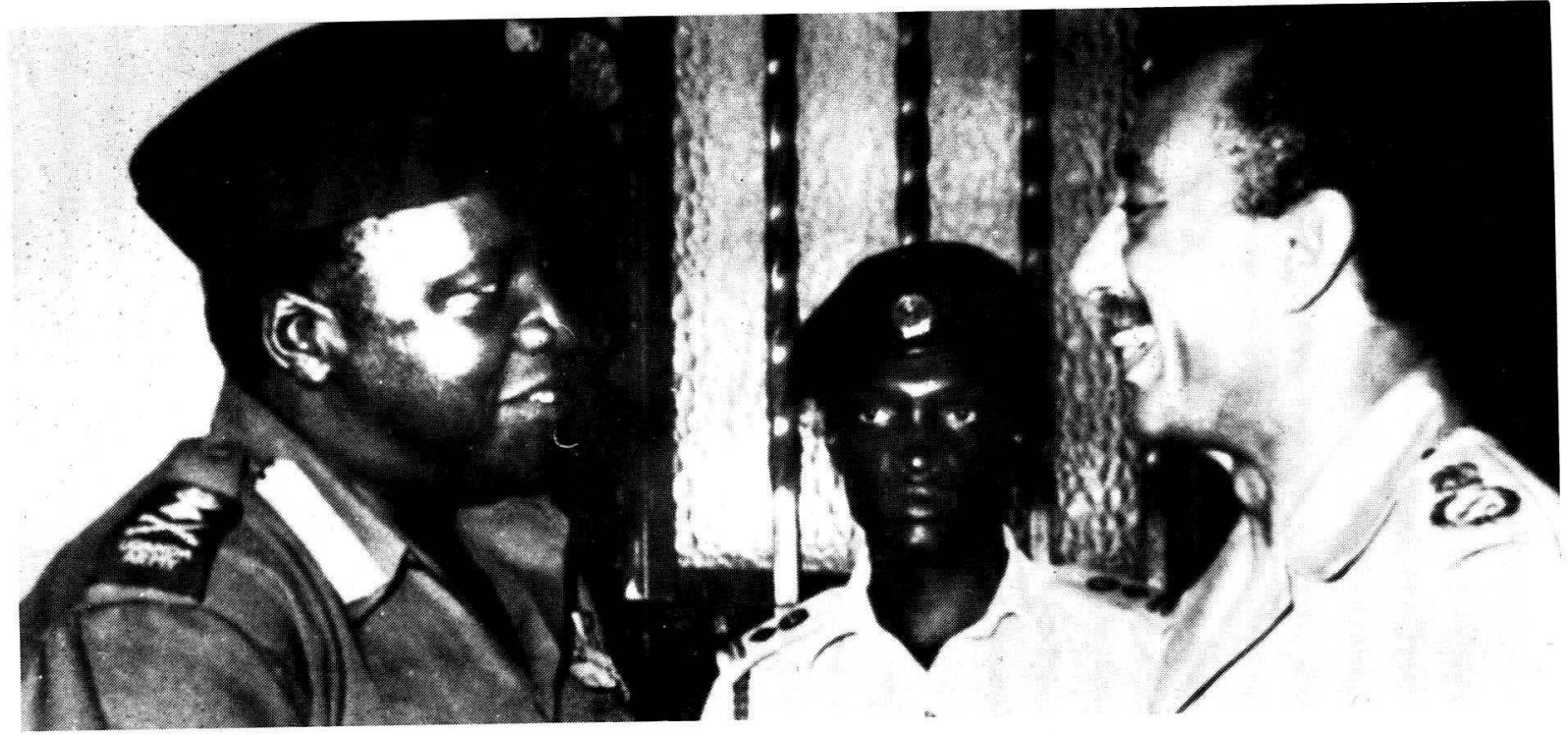

(Photo: Buro of National and International

Communication.)

President Idi Amin of Uganda and President Sadat of Egypt. 
15. J.M. Lee: African armies and civil order, (1969

16. R.K. Mapp: Domestic correlates of military intervention in African politics. Paper presented at the Canadian Political Science Association, Winnipeg, Canada, 1970

17. D.C. Rapoport: A comparative theory of military and political types (In S.P. Huntington (ed): Changing Patterns of Military Politics)(New York, 1962)

18. C.E. Welch, jr: Continuity and discontinuity in African military organisations. Paper presented at the third International Congress of Africanists, Addis Ababa, 1973.

19. C.E. Welch: Soldier and State in Africa, (1970)

20. D. Wood: The armed forces of African states (In Adelphi Papers, no 27, April 1966)

21. African Affairs, vol 77, no 307, April 1978 (P. Woodward: Ambiguous Amin.) 